\title{
Abundance and Distribution of Tetracycline Resistance Genes and Mobile Elements in an Oxytetracycline Production Wastewater Treatment System
}

\author{
Miaomiao Liu, ${ }^{\dagger}$ Yu Zhang, ${ }^{\dagger}$ Min Yang, ${ }^{* \dagger}{ }^{\dagger}$ Zhe Tian, $^{\dagger}$ Liren Ren, ${ }^{\ddagger}$ and Shujun $Z_{\text {hang }}{ }^{\S}$ \\ ${ }^{\dagger}$ State Key Laboratory of Environmental Aquatic Chemistry, Research Center for Eco-Environmental Sciences, Chinese Academy of \\ Sciences, P.O. Box 2871, Beijing 100085, China \\ ${ }^{\ddagger}$ Institute of Environmental Science and Technology, North China Pharmaceutical Group Corporation, Hebei, China

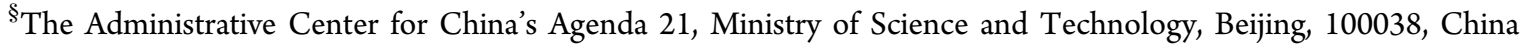

Supporting Information

ABSTRACT: We investigated the abundance and distribution of tetracycline resistance genes (tet genes) in an oxytetracycline (OTC) antibiotic production wastewater (APW) treatment system. Of sixteen tet genes and five mobile elements, nine tet genes $(\operatorname{tet}(\mathrm{A}), \operatorname{tet}(\mathrm{C}), \operatorname{tet}(\mathrm{G}), \operatorname{tet}(\mathrm{L})$, tet $(\mathrm{M}), \operatorname{tet}(\mathrm{O}), \operatorname{tet}(\mathrm{Q})$, tet $(\mathrm{W})$, and $\operatorname{tet}(\mathrm{X}))$ and two mobile elements (class 1 integron (intI1) and transposon Tn916/ 1545 ) were successfully quantified by real-time PCR. The relative abundance of tet genes in the effluent and activated sludge $\left(1.2 \times 10^{-4}\right.$ to $\left.1.3 \times 10^{0}\right)$ of the APW treatment system were up to 2 orders of magnitude higher than those in the OTC fermentation residues $\left(8.5 \times 10^{-5}\right.$ to $\left.6.7 \times 10^{-3}\right)(P<$

$0.01)$, and 1-4 orders of magnitude higher than those in sewage and nonantibiotic production wastewater treatment systems $(P$ $<0.01$ ), showing that the discharge of abundant tet genes from the APW treatment system is worthy of attention. The three most abundant genes in the APW treatment system, tet $(\mathrm{A})$, tet $(\mathrm{C})$, and $\operatorname{tet}(\mathrm{G})$, exhibited significant positive correlations with intI1 $\left(R^{2}\right.$ $=0.73,0.95$, and 0.83 , respectively; $P<0.05)$, suggesting that intI1 may be involved in their proliferation. This is the first study showing that some measures may be required to control the discharge of antibiotic resistance genes from treated APW and activated sludge.

\section{INTRODUCTION}

Widespread antibiotic resistant bacteria and resistance genes (ARGs) have caused increasing concern worldwide, ${ }^{1}$ leading to the regulation of antibiotic use in hospitals and clinics, as well as in agriculture and aquaculture. ${ }^{2,3}$ Antibiotic production wastes (fermentation residues and waste mother liquors) have been listed as hazardous wastes in some countries due to the presence of high levels of residual antibiotics. ${ }^{4,5}$ China has also prohibited the use of fermentation residues as animal food additives. $^{6}$ Waste mother liquors are normally treated using biological processes after dilution with other waste streams. ${ }^{7}$ The high antibiotic concentrations and bacterial densities in antibiotic production wastewater (APW) treatment systems make it easy for bacteria to acquire resistance and proliferate ARGs, ${ }^{8}$ which can be transferred among environmental bacteria and pathogens, and pose health risks to humans via various pathways. ${ }^{9}$ Our previous study successfully isolated abundant multiantibiotic resistant bacteria harboring diverse tetracycline resistance genes (tet genes) from an oxytetracycline (OTC) production wastewater treatment plant. ${ }^{10}$ However, the abundance of ARGs in treated APW and activated sludge, which are discharged into the environment, have not yet been clarified.

As one of the most commonly used human and veterinary medicines, broad-spectrum tetracycline antibiotics are produced in large amounts around the world. Tet genes in the environment have been extensively studied in sewage treatment plants (STPs), ${ }^{11}$ animal lagoons, ${ }^{12}$ and fish farming ponds, ${ }^{13}$ where tetracyclines have been frequently detected. Among the 44 known tet genes, more than 29 have been found in the environment. $^{10,11,14}$ For example, 7-13 tet genes have been detected in 15 STPs from different regions, with efflux protein (EFP) gene tet $(\mathrm{G})$ the most abundant followed by tet $(\mathrm{A})$ and tet $(\mathrm{C}) .^{11}$ Additionally, ribosomal protection proteins (RPP) tet $(\mathrm{O})$, tet $(\mathrm{Q})$, and tet $(\mathrm{W})$ have been found the most abundant in three United States STPs, ${ }^{15}$ while RPP tet $(\mathrm{M})$, tet $(\mathrm{O})$, tet $(\mathrm{Q})$, and tet $(\mathrm{W})$ have been detected in high abundance in animal feedlot lagoons. ${ }^{12,16}$ In our previous study, tet genes

Received: March 24, 2012

Revised: May 25, 2012

Accepted: June 18, 2012

Published: June 18, 2012 
were detected in the majority of bacterial isolates from treated OTC production wastewater, with tet $(\mathrm{A})$ and $\operatorname{tet}(\mathrm{C})$ being the most frequently detected. ${ }^{10}$ The distribution of tet genes appears to vary among different environments, which may be associated with bacterial compositions, antibiotic levels, horizontal gene transfer, etc. ${ }^{1,8,17}$ It is not clear, however, how tet genes are distributed in the APW treatment system, and what important factors affect their distribution.

The main target of this study was to understand the abundance and distribution of tet genes in an APW treatment system that mainly receives production wastewater from an OTC manufacturing plant in northern China. Among the 16 tet genes determined using PCR, 11 detected tet genes were quantified for all samples, including the antibiotic production waste, using real-time PCR. To understand the potential mechanisms for the distribution of tet genes, some important mobile elements were also quantified using real-time PCR, and the diversities of tet(C), tet $(\mathrm{M})$, and $\operatorname{tet}(\mathrm{X})$ as well as bacterial $16 \mathrm{~S}$ rRNA genes were analyzed by constructing clone libraries. For the first time, this study revealed the intensity and compositions of tet genes discharged from an APW treatment system.

\section{EXPERIMENTAL SECTION}

Study Facilities, Sampling Sites, and Characterization of Samples. More than 1000 tons of OTC are produced every year in the studied antibiotic manufacturing plant in Hebei Province, China. Following slab filtration and OTC extraction (SI Figure S1.a), the OTC waste mother liquor (OTC-ML) is diluted by machine washing water and a small amount of sewage within the plant to produce an average flow of $5000 \mathrm{~m}^{3}$ $\mathrm{day}^{-1}$. The mixed wastewater is then treated by a biological system which includes a sequential batch reactor (SBR) and a two-stage submerged biological contact reactor using fiber bundle as the biocarrier (SI Figure S1.b). The hydraulic retention time is $8 \mathrm{~h}$ for each reactor. The final effluent from the APW treatment system is discharged into a nearby river. The concentration of mixed liquor suspended solids in the SBR is maintained at $4000-5000 \mathrm{mg} / \mathrm{L}$. One cycle of the SBR includes four operational steps, namely filling $(1 \mathrm{~h})$, aeration (5 $\mathrm{h})$, settling $(1.5 \mathrm{~h})$, and decanting $(0.5 \mathrm{~h})$. This APW treatment system has been in use since 2000 .

Water samples from the APW treatment system, including the influent (W1) and the final effluent (W2), were collected with 24-h composite samples taken every $4 \mathrm{~h}$ four times (March and June 2009, January 2010, and January 2012). Activated sludge samples of the SBR (S1) and the biological contact reactor (S2) were collected in January 2010 and January 2012. The OTC production waste was collected from the production workshop in May 2010. The OTC fermentation residue (OTCFR) was collected as soon as it was separated from the OTC fermentation broths. Waste OTC mother liquor (OTC-ML) was collected from its storage tanks. Samples were kept below 4 ${ }^{\circ} \mathrm{C}$ until pretreatment or analysis, which was conducted within $48 \mathrm{~h}$. Aerobic activated sludge samples from two nonantibiotic (inosine and ethanol) production wastewater treatment plants were collected as control systems, because these facilities only receive inosine and ethanol production wastewater and sewage, respectively.

Chemical and biological characteristics and concentrations of OTC related compounds (OTC and its three hydrolysates, 4epi-OTC, $\alpha$-Apo-OTC, and $\beta$-Apo-OTC) were determined as described previously, ${ }^{18,19}$ with related methods briefly presented in the Supporting Information. All samples were analyzed in duplicate or triplicate. The average results are summarized in SI Table S1-S2.

DNA Extraction and PCR. Ten $\mathrm{mL}$ of each wastewater sample was filtered through $0.22-\mu \mathrm{m}$ polycarbonate membranes (GTTP, Millipore, Ireland), and biomass on the membranes was collected in 2-mL sterilized tubes for DNA extraction using the Proteinase K method. ${ }^{20}$ Sludge samples were centrifuged at $10000 \mathrm{rpm}$ for $10 \mathrm{~min}$ at $4{ }^{\circ} \mathrm{C}$, and $0.25 \mathrm{~g}$ (wet weight) of sediment for each sample was used for DNA extraction using a FastDNA SPIN kit for soil (Qbiogene, Solon $\mathrm{OH}$ ). The volumes of DNA solutions from the water and sludge samples were 50 and $80 \mu \mathrm{L}$, respectively. Concentrations and quality of the extracted DNA were checked by spectrophotometric analysis on a NanoDrop ND-1000 (Nanodrop, USA) and electrophoresis on a $1 \%$ (weight/volume) agarose gel.

Sixteen tet genes (six RPP genes $(\operatorname{tet}(\mathrm{M}), \operatorname{tet}(\mathrm{O}), \operatorname{tet}(\mathrm{Q})$, tet $(\mathrm{T})$, tet $(\mathrm{W})$, and $\operatorname{tet} \mathrm{B}(\mathrm{P}))$, nine $\mathrm{EFP}$ genes $(\operatorname{tet}(\mathrm{A})$, tet $(\mathrm{C})$, $\operatorname{tet}(\mathrm{D}), \operatorname{tet}(\mathrm{E}), \operatorname{tet}(\mathrm{G}), \operatorname{tet}(\mathrm{K}), \operatorname{tet}(\mathrm{L}), \operatorname{tet}(\mathrm{Z})$, and $\operatorname{tet} A(\mathrm{P}))$ and one inactivating enzyme tet $(\mathrm{X}))$ and five mobile elements (Class 1 to 4 integrons (intI1-intI4) and transposon Tn916/ 1545) were investigated. The PCR assays for DNA extracted from the SBR activated sludge (S1) were conducted in $25-\mu \mathrm{L}$ volume reactions using an ABI PCR System 9700 (ABI, USA). The PCR mixture consisted of $1 \times$ rTaq buffer, $5 \mathrm{nM}$ dNTP, $0.625 \mathrm{U}$ Ex Taq (Takara, Japan), $400 \mathrm{nM}$ each primer, $0.5 \mathrm{mg}$ $\mathrm{mL}^{-1} \mathrm{BSA}$, and $1-2 \mu \mathrm{L}$ of DNA. Primers targeting the sixteen tet genes and five mobile elements were selected from published literature, ${ }^{21-25}$ with their amplification sizes and conditions listed in SI Table S3. The temperature program consisted of initial denaturation at $95{ }^{\circ} \mathrm{C}$ for $5 \mathrm{~min}$, followed by 35 cycles of $30 \mathrm{~s}$ at $95{ }^{\circ} \mathrm{C}, 30 \mathrm{~s}$ at different annealing temperatures and extension at $72{ }^{\circ} \mathrm{C}$ for $45 \mathrm{~s}$, and finished with a final extension step at $72{ }^{\circ} \mathrm{C}$ for $7 \mathrm{~min}$. Sterile water was used as the negative control in each run. The PCR products were checked by electrophoresis on a $1 \%$ (weight/volume) agarose gel in $1 \times$ TBE buffer. The positive amplicons were further assured by cloning and sequencing.

Real-Time PCR. Eleven detected tet genes (tet(A), tet $(\mathrm{C})$, $\operatorname{tet}(\mathrm{E}), \operatorname{tet}(\mathrm{G}), \operatorname{tet}(\mathrm{K}), \operatorname{tet}(\mathrm{L}), \operatorname{tet}(\mathrm{M}), \operatorname{tet}(\mathrm{O}), \operatorname{tet}(\mathrm{Q}), \operatorname{tet}(\mathrm{W})$, and tet $(\mathrm{X})$ ), three detected mobile elements (intI1, intI2, and Tn916/1545), and the 16S rRNA gene were quantified for all samples using SYBR-Green real-time PCR. Standard plasmids carrying target genes were obtained by TA clones and extracted using a TIANpure Mini Plasmid kit (Tiangen, China). ${ }^{26}$ Concentrations of the standard plasmids (ng $\mu \mathrm{L}^{-1}$ ) were determined with the Nanodrop ND-1000 (Nanodrop, USA). Their copy concentrations (copies $\mu \mathrm{L}^{-1}$ ) were then calculated by the following formula. ${ }^{27}$

$$
\begin{aligned}
& \text { copy concentration }\left(\text { copies } \mu \mathrm{L}^{-1}\right) \\
& =\frac{\text { DNA mass concentration }\left(\mathrm{ng} \mu \mathrm{L}^{-1}\right)}{\text { DNA molecular weight }\left(\mathrm{g} \mathrm{mol}^{-1}\right)} \times 6.02 \times 10^{23} \\
& \quad \times 10^{-9}
\end{aligned}
$$

The $25-\mu \mathrm{L}$ reactions typically contained $1 \times$ Sybr Green I, 1 $\times$ Dye (Takara), $200 \mathrm{nM}$ each primer, $0.5 \mathrm{mg} \mathrm{mL}^{-1} \mathrm{BSA}$, and 2 $\mu \mathrm{L}$ of DNA templates. Real-time PCR was run on an ABI7300 apparatus (ABI, USA) by the following program: $95^{\circ} \mathrm{C}$ for 30 s, and 40 cycles consisting of the following: (i) $95{ }^{\circ} \mathrm{C}$ for $10 \mathrm{~s}$, (ii) annealing temperature for $15 \mathrm{~s}$, (iii) $72^{\circ} \mathrm{C}$ for $15 \mathrm{~s}$, and (iv) $78{ }^{\circ} \mathrm{C}$ for $26 \mathrm{~s}$ to collect the fluorescent signals. The melting 
process was automatically generated by the ABI7300 software. Triplicate real-time PCR assays were performed for the decimally diluted standard plasmids to obtain the standard curves. Duplicate real-time assays were performed for all samples and negative controls. To prevent the inhibition of the sample matrix, 10-100 fold diluted samples were used for quantification.

The following requirements were satisfied to obtain reliable quantification: $R^{2}$ higher than 0.99 for standard curves over 5 orders of magnitude and amplification efficiencies based on slopes between $90 \%$ and $110 \%$ (SI Table S4). The specificity was assured by the melting curves and gel electrophoresis. Gene copies per sample volume are shown in SI Table S5. To minimize the variance caused by different bacterial abundance, as well as different DNA extraction and quantification efficiencies, the relative abundance of tet genes and mobile elements was obtained by normalizing their copy numbers to those of the 16S rRNA genes (SI Table S6). ${ }^{28}$

Cloning and Phylogenetic Analysis of tet Genes. Clone libraries of tet $(\mathrm{C})$, tet $(\mathrm{M})$, and $\operatorname{tet}(\mathrm{X})$, which represent three different resistance mechanisms, were constructed for OTC-FR, OTC-ML, W1, W2, and S1. The target gene fragments were amplified in triplicate using the same primers as for PCR and real-time PCR. Combined amplification products of the triplicate PCR assays were purified by a Fermentas GeneJET gel extraction kit (Thermo, USA), followed by inserting into the pMD-18T cloning vector (Takara) and transforming into JM109 Escherichia coli (Takara). Transformants were further selected by blue-white screen with X-Gal and confirmed by PCR with plasmid vector-specific primers M13F and M13R using $55^{\circ} \mathrm{C}$ as the annealing temperature. Positive clones were randomly selected for sequencing on an $\mathrm{ABI} 3300$ sequencing machine (ABI, USA). Sequences were subjected to homology analysis using the software Lasergene version 7 (DNAStar, USA). Sequences that exhibited more than $98 \%$ identity to each other were considered as one type, from which only one representative sequence was chosen to construct the phylogenetic trees. Online similarity searching was performed using the NCBI BLAST tool, and the most similar GenBank sequences were included in the neighbor-joining trees using MEGA version 4.1 (http://megasoftware.net/). Bootstrap analysis with 1000 replicates was used to evaluate the significance of the nodes. The sequences of tet $(\mathrm{M})$ obtained in this study were deposited in the European Nucleotide Archive gene bank under Accession number HE580463 to HE580643, and the sequences of tet $(\mathrm{C})$ and tet $(\mathrm{X})$ were deposited in the NCBI GenBank under Accession number JQ668333 to JQ668515.

Cloning and Phylogenetic Analysis of the 16S rRNA Genes. Clone libraries of the $16 \mathrm{~S}$ rRNA genes were constructed for OTC-FR, OTC-ML, W1, W2, and S1 using primers $27 \mathrm{~F}$ and $1492 \mathrm{R}$ by the same procedure as the above tet genes. $^{29}$ Classification of the operational taxonomic units (OTUs), and calculation of coverage and Shannon index were carried out using Dotur software. ${ }^{30}$ The 16S rRNA gene sequences obtained in this study were deposited in the NCBI GenBank under Accession number JN245629 to JN245879.

Data Analysis. All statistical analyses were performed using SPSS version 15.0. Paired samples $t$ test was used to assess the significance of the differences between different systems and samples based on $P$-values. Pearson's bivariate correlation analysis was used to assess the relation among tet genes and mobile elements.

\section{RESULTS}

Concentrations of OTC Related Compounds. As summarized in SI Table S2, the total concentrations of OTC related compounds (OTC and its three hydrolysates) were extremely high in the OTC fermentation residues (OTC-FR) $\left(44102.7 \mathrm{mg}(\mathrm{kg} \text { dry weight })^{-1}\right)$ and waste OTC mother liquors (OTC-ML) (1074.9 to $1479.8 \mathrm{mg} \mathrm{L}^{-1}$ ). The total concentrations were $1.14-12.36 \mathrm{mg} \mathrm{L}^{-1}$ in the SBR influent (W1) and $0.36-2.35 \mathrm{mg} \mathrm{L}^{-1}$ in the final effluent (W2) and were as high as $40.7-170.2 \mathrm{mg}$ ( $\mathrm{kg}$ dry weight) $)^{-1}$ in the activated sludge (S1 and S2), showing the adsorption of antibiotics by biomass.

Abundance of tet Genes and Mobile Elements. Among the sixteen tet genes and five mobile elements examined by $\mathrm{PCR}$, eleven tet genes $(\operatorname{tet}(\mathrm{A}), \operatorname{tet}(\mathrm{C}), \operatorname{tet}(\mathrm{E}), \operatorname{tet}(\mathrm{G}), \operatorname{tet}(\mathrm{K})$, $\operatorname{tet}(\mathrm{L}), \operatorname{tet}(\mathrm{M}), \operatorname{tet}(\mathrm{O}), \operatorname{tet}(\mathrm{Q}), \operatorname{tet}(\mathrm{W})$, and tet $(\mathrm{X}))$ and three mobile elements (intI1, intI2, and Tn916/1545) were detected in the SBR activated sludge sample (S1) collected in March 2009. These tet genes and mobile elements were then quantified by real-time PCR for the OTC production waste and samples from the APW treatment system.

Except for tet(E), tet $(\mathrm{K})$, and intI2, all other genes were detected by real-time PCR in all samples. As shown in SI Table S5, the highest abundance of tet genes and mobile elements per sample volume was observed in the sludge samples ( $\mathrm{S} 1$ and S2), where individual tet genes ranged from $5.7 \times 10^{6}$ to $6.7 \times$ $10^{9}$ copies $/ \mathrm{mL}$ with the total tet genes $\left(\right.$ tet $\left.^{\mathrm{T}}\right)$ at the level of $10^{10}$ copies $/ \mathrm{mL}$, and mobile elements ranged from $2.2 \times 10^{6}$ to 1.6 $\times 10^{10}$ copies $/ \mathrm{mL}$. The gene abundance per sample volume in the APW treatment system (W1, W2, S1, and S2) was significantly higher than those in the OTC production waste (OTC-FR and OTC-ML) $(P<0.05)$. Since the biomass contents could affect the gene abundance, ${ }^{12}$ relative abundance of tet genes and mobile elements (gene copies per 16S rRNA gene) was used for further analyses (Figure 1, SI Figure S2, and SI Table S6).

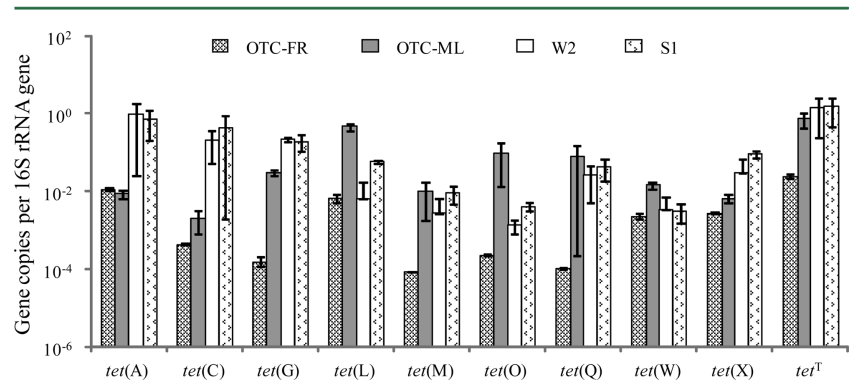

Figure 1. Relative abundance of tet genes (gene copies per 16S rRNA gene) in samples from the OTC production and APW treatment systems. tet $^{\mathrm{T}}$ is the total relative abundance of the 9 tet genes. Columns are the mean values of 2-4 sampling campaigns. Error bars represent the standard deviations.

In OTC-FR, the relative abundance of individual tet genes was in the range of $8.5 \times 10^{-5}$ to $1.0 \times 10^{-2}$, with tet ${ }^{\mathrm{T}}$ at $2.4 \times$ $10^{-2}$. In OTC-ML, the relative abundance of individual tet genes was in the range of $2.7 \times 10^{-4}$ to $3.6 \times 10^{-1}$, with tet ${ }^{T}$ at $7.1 \times 10^{-1}$ (SI Table S6). tet $(\mathrm{A})$, tet $(\mathrm{C})$, and $\operatorname{tet}(\mathrm{G})$ were the three most dominant tet genes in the effluent and activated sludge of the APW treatment system (W2, S1, and S2), ranging from $7.2 \times 10^{-2}$ to $1.7 \times 10^{0}$, followed by tet $(\mathrm{X})$ at the level of $2.9 \times 10^{-2}$ to $1.0 \times 10^{-1}$ (Figure 1, SI Table S6). Compared to the relative abundance in influent, $\operatorname{tet}(\mathrm{G})$ increased in the 
effluent while tet $(\mathrm{L})$, tet $(\mathrm{M})$, tet $(\mathrm{Q})$, and tet $(\mathrm{W})$ decreased $(P<$ $0.05)$, with other genes and the total tet genes $\left(\right.$ tet $\left.^{\mathrm{T}}\right)$ showing no significant change after treatment $(P>0.05)$ (SI Figure S2).

As shown in SI Table S6, the relative abundance of intI1 was about $1.1 \times 10^{-1}$ in OTC-ML, higher than that in OTC-FR $\left(3.5 \times 10^{-4}\right)$. The relative abundance of intIl was $2.2 \times 10^{-1}$ to $3.2 \times 10^{0}$ in the effluent (W2) and sludge samples (S1 and S2) of the APW treatment system. In addition, Tn916/1545 was $1.7 \times 10^{-6}$ and $1.0 \times 10^{-1}$ in OTC-FR and OTC-ML, respectively, and $4.9 \times 10^{-4}$ to $1.5 \times 10^{-2}$ for samples from the APW treatment system. Similar to a previous study, ${ }^{28}$ Tn916/ 1545 showed a positive correlation with tet(M) during treatment $\left(R^{2}=0.48, P<0.05\right.$, SI Figure S3), indicating that Tn916/1545 may be responsible for the transfer of tet $(M)$.

Cloning and Phylogenetic Analysis of tet(C), tet(M), and tet $(\mathrm{X})$. Clone libraries of tet $(\mathrm{C})$, tet $(\mathrm{M})$, and tet $(\mathrm{X})$ were constructed for OTC-FR, OTC-ML, W1, W2, and S1. BLAST searches in the NCBI GenBank database confirmed that all the sequenced clones matched known tet $(\mathrm{C})$, tet $(\mathrm{M})$, and tet $(\mathrm{X})$ genes, with identities between $98 \%$ and $100 \%$. The phylogenetic trees of tet(C), tet( $\mathrm{M})$, and tet(X) are shown in SI Figures S4-S6. The distributions of tet(C) and tet(M) are shown in SI Table S7 and Table 1, respectively.

Table 1. Distribution of Phylogenetic Groups among tet(M) Clone Libraries for the Samples from the OTC Production and APW Treatment Systems

\begin{tabular}{lccccc} 
& \multicolumn{5}{c}{ percentage of each type to total no. of clones (\%) } \\
\cline { 2 - 6 } type & OTC-FR & OTC-ML & W1 & W2 & S1 \\
Type 1 & 97.2 & 71.4 & 81.6 & 23.3 & 38.1 \\
Type 2 & 2.8 & 20.0 & 8.9 & $-a$ & 2.4 \\
Type 3 & - & - & - & 3.3 & - \\
Type 4 & - & - & - & 3.3 & - \\
Type 5 & - & 8.6 & 10.5 & 66.7 & 59.5 \\
Type 6 & - & - & - & 3.3 & - \\
NO. of clones & 36 & 35 & 38 & 30 & 42 \\
a“.”: absent. & & & & & \\
\hline
\end{tabular}

The tet(C) sequences were divided into 4 types (SI Figure S4). Type 1, which was identical to the tet(C) sequences in Escherichia coli (EU751610-EU751613), Escherichia coli plasmid (Y19114), and Francisella tularensis plasmid (NC_002109), was the most dominant type for all samples. Type 2 was found in OTC-FR and OTC-ML at the frequency of $19.0 \%$ and $13.0 \%$, while Type 3 was found in OTC-FR at the frequency of $4.8 \%$, and Type 4 was found in OTC-ML at the frequency of $4.3 \%$ (SI Table S7).

The tet $(\mathrm{M})$ clones were sorted into six types (Type 1-Type 6) according to the homology analysis (SI Figure S5). As shown in Table 1, Type 1, which was identical to the tet $(\mathrm{M})$ sequences found in various plasmids, conjugative transposons, and chromosomes of both gram-negative and gram-positive bacteria, was dominant $(81.6 \%-97.2 \%)$ in the clone libraries of OTC-FR, OTC-ML, and W1, but was less abundant in W2 (23.3\%) and S1 (38.1\%). Type 5, which was 99\% identical to the tet(M) sequences in Streptococcus agalactiae (GU318219), Streptococcal conjugative shuttle transposon Tn1545 (X04388), and Streptococcus pneumoniae partial transposon Tn1545 (AM889142), became dominant in W2 and S1 (59.5\%). Types 2, 3, 4, and 6 were detected with relatively low abundance $(2.4 \%-20.0 \%)$.
The tet $(\mathrm{X})$ sequences in OTC-ML, W1, W2, and S1 showed a very conservative type identical to those in Sphingobacterium (EU864422) and Bacteroides Transposon Tn4351 (M37699) (SI Figure S6). Cloning of tet(X) was not obtained for OTCFR.

Cloning and Phylogenetic Analysis of the 16S rRNA Genes. Clone libraries of the 16S rRNA genes were constructed for OTC-FR, OTC-ML, W1, W2, and S1, with 40-68 clones sequenced for each sample (SI Table S8). Streptomyces, which has been used as OTC production bacterium, ${ }^{31}$ was dominant $(61.5 \%)$ in OTC-FR, but disappeared in the subsequent samples (OTC-ML, W1, W2, and S1). Class Bacilli was abundant in OTC-FR (33.3\%) and OTC-ML (63.4\%). In the influent (W1), classes Clostridia and Bacteroidetes accounted for $27.4 \%$ and $21.9 \%$ of the total clone numbers, followed by Gammaproteobacteria and Bacilli (16.4\% and $11.0 \%$, respectively). In the effluent (W2), Betaproteobacteria was the most abundant (44.3\%) followed by many unclassified bacteria (24.6\%). For the activated sludge (S1), Class Betaproteobacteria was dominant (42.6\%) followed by Bacteroidetes (25.9\%). The distribution of gram-positive (G+) and gram-negative $(\mathrm{G}-)$ bacteria in all $16 \mathrm{~S}$ rRNA gene clone libraries is summarized in Table 2 . The $\mathrm{G}+$ bacteria were dominant in OTC-FR (97.4\%) and OTC-ML (73.2\%), while G- bacteria became dominant in W2 (67.2\%) and S1 (100\%).

Table 2. Distribution of Gram-Positive and Gram-Negative Bacteria among the 16S rRNA Gene Clone Libraries for the Samples from the OTC Production and APW Treatment Systems

\begin{tabular}{cccccc} 
& \multicolumn{5}{c}{ percentage of Clones (\%) } \\
\cline { 2 - 6 } bacterial group & OTC-FR & OTC-ML & W1 & W2 & \multicolumn{1}{c}{ S1 } \\
gram-positive & 97.4 & 73.2 & 42.6 & 6.9 & - $^{a}$ \\
gram-negative & 2.6 & 26.8 & 51.5 & 67.2 & 100.0 \\
unclassified & - & - & 5.9 & 25.9 & - \\
a“ _": absent. & & & & & \\
\hline
\end{tabular}

\section{DISCUSSION}

Worldwide annual output of the tetracycline class of antibiotics has reached more than 20000 tons. ${ }^{32}$ During OTC production, waste mother liquor containing OTC related compounds at concentrations of over $1000 \mathrm{mg} \mathrm{L}^{-1}$ is generated and treated with biological processes after dilution. ${ }^{7}$ As summarized in SI Table S1, high levels of OTC related compounds were observed in the wastewater $\left(0.36-12.36 \mathrm{mg} \mathrm{L}^{-1}\right)$ and activated sludge samples $\left(40.5-170.2 \mathrm{mg}(\mathrm{kg} \text { dry weight })^{-1}\right){ }^{33}$ which were much higher than those previously reported in other environments, such as STPs $\left(0.06-1.10 \mu \mathrm{g} \mathrm{L}^{-1}\right),{ }^{34}$ hospital wastewater $\left(<100 \mu \mathrm{g} \mathrm{L}^{-1}\right),{ }^{35}$ animal feces $(1.15-145.75 \mu \mathrm{g}$ $\left.\mathrm{L}^{-1}\right){ }^{36,37}$ and soils adjacent to swine farms $(5.36-377.77 \mu \mathrm{g}$ (kg dry weight $\left.)^{-1}\right)^{32}$

It is well accepted that ARGs are selected and enriched by antibiotic residues. ${ }^{8}$ SI Table S9 compares the relative abundance of tet genes in the effluent and sludge from the APW treatment system with those from STPs and the control systems receiving inosine and ethanol production wastewater. The relative abundance of tet genes in the activated sludge from the APW treatment system was 1-4 orders of magnitude higher than those in STPs and the control systems $(P<$ $0.01) .^{11,38-40}$ This comparison clearly shows that high fluxes of 
tet genes could be released into the environment through the discharge of treated effluents and the disposal of excess sludge from an APW treatment system.

Antibiotic fermentation residues and waste mother liquors have been listed as hazardous wastes in some countries, and antibiotic fermentation residues have been prohibited as animal food additives in China since 2002. ${ }^{4-6}$ Our results (Figure 1) showed that the effluent and activated sludge from the APW treatment system contained higher levels of tet genes than the OTC fermentation residues $(P<0.01)$, and had no significantly different gene levels from the OTC mother liquors $(P>0.05)$. There are indications that tet genes may be able to spread from environmental bacteria to pathogens after being discharged into the environment. ${ }^{10}$ Thus health risks posed by the discharge of treated APW and activated sludge should be evaluated from the aspect of ARGs, and proper regulations to manage these two release routes are required to control the proliferation of ARGs in the environment.

In the activated sludge of the APW treatment system, efflux protein (EFP) genes tet(A), tet(C), and tet(G) were the most abundant, followed by the enzymatic modification gene tet(X) (SI Table S6). Zhang et al. reported that, among thirteen tet genes, $\operatorname{tet}(\mathrm{G})$ was the most abundant followed by tet(A) and tet $(\mathrm{C})$ in ten out of fifteen STPs, while tet(A) and tet(C) were more abundant in the other five STPs. ${ }^{11}$ Our former study has also shown that tet(A) and tet(C) were the most frequently detected tet genes in bacteria isolated from the same APW treatment system $\left(69.3 \%\right.$ and $42.9 \%$, respectively), ${ }^{10}$ where tet $(\mathrm{G})$ was not detected, perhaps due to the use of a different primer set. ${ }^{22}$ Thereby, EFP genes tet(A), tet (C), and tet (G) could prevail in wastewater treatment systems with different levels of residual antibiotics. However, RPP genes tet $(\mathrm{O})$, tet $(\mathrm{Q})$, and $\operatorname{tet}(\mathrm{W})$ were found to be the most abundant tet genes in three American STPs. ${ }^{15}$ Research conducted in animal feedlot lagoons found that RPP genes tet $(\mathrm{M}), \operatorname{tet}(\mathrm{O}), \operatorname{tet}(\mathrm{Q})$, and tet $(\mathrm{W})$ were more abundant than EFP genes tet $(\mathrm{B})$, tet $(\mathrm{C})$, and $\operatorname{tet}(\mathrm{L}) \cdot{ }^{12,16} \mathrm{Hu}$ et al. only $\operatorname{detected} \operatorname{tet}(\mathrm{A}), \operatorname{tet}(\mathrm{B})$, and tet(M) among twenty tet genes in tetracycline resistant Escherichia coli isolated from a natural river. ${ }^{41}$ Thus, the different distribution patterns of tet genes in different environments may be associated with bacterial compositions, antibiotic levels, horizontal gene transfer, etc. ${ }^{1,8,17}$ As will be discussed below, the dominance of $\operatorname{tet}(\mathrm{A}), \operatorname{tet}(\mathrm{C})$, and tet $(\mathrm{G})$ in our study was likely related with the host compositions and their potential transfer ability, both of which could be affected by the high antibiotic concentrations in the APW treatment system.

Generally, G+ bacteria mainly harbor RPP tet genes and a few EFP tet genes including $\operatorname{tet}(\mathrm{K}), \operatorname{tet}(\mathrm{L}), \operatorname{tet}(\mathrm{Z})$ and $\operatorname{tet}(\mathrm{T})$, while G- bacteria harbor both EFP and RPP tet genes, with EFP tet genes dominating. ${ }^{17}$ In the present study, tet $(\mathrm{L})$ was the most abundant gene in OTC-ML, which may be related to the dominance of $\mathrm{G}+$ bacteria $(73.2 \%)$. On the other hand, the dominance of $\mathrm{G}-$ bacteria in the effluent and activated sludge (Table 2) may have allowed EFP genes tet(A), tet(C) and tet $(\mathrm{G})$ to prevail and even increase during the APW treatment. The relative abundance of total tet genes was low $\left(10^{-2}\right)$ in OTC-FR, which was dominated with Streptomyces and Bacilli (SI Table S8). As a production bacterium, Streptomyces may have different self-protection mechanisms, resulting in low abundance of tet genes. ${ }^{42,43}$

Horizontal gene transfer, which could be carried out by mobile elements, including integrons, conjugative transposons, and plasmids, is a very important pathway for ARGs' proliferation, especially under antibiotic selection pressure. $^{16,44,45}$ As shown in SI Figure S7, tet(A), tet(C), and tet $(\mathrm{G})$ exhibited significant positive correlations with intI1 $\left(\mathrm{R}^{2}\right.$ $=0.84,0.95$, and 0.83, respectively; $P<0.05)$. In our previous study, tet(A), tet(C), and intIl were detected with high frequencies in antibiotic resistant bacteria isolated from the same APW treatment plant. ${ }^{10}$ As the most common integron, intI1 is reported to integrate and express more than 100 types of resistance genes by gene cassettes, most of which are aminoglycoside and trimethoprim resistance genes and $\beta$ lactamases. ${ }^{46}$ Although no tet genes have yet been detected in any gene cassette of intI1, some studies have shown that intI1 can accrete noncassette resistance genes outside the cassette region by the "insertion sequence common region" (ISCR), a newly highlighted complex integron element usually linked to intI1. ${ }^{47}$ Previous findings have revealed that intIl coexists with tet $(\mathrm{A})$ and tet $(\mathrm{C})$ in conjugative plasmids by which they can be easily cotransferred into recipients. ${ }^{48,49}$ Moreover, tet(A) and tet $(\mathrm{G})$ have been found on ISCR2 and ISCR3, the latter of which is linked to intI1. ${ }^{47}$ Thus, intIl may play certain roles in the transfer of tet(A), tet $(\mathrm{C})$, and $\operatorname{tet}(\mathrm{G})$, resulting in the dominance and increase of these genes in the APW treatment system.

According to the sequences from the NCBI GenBank, tet $(\mathrm{M})$ has diverse types, which makes it suitable for source tracking of tet genes. ${ }^{23,50}$ As shown in Table 1, OTC-FR, OTC-ML, and W1 shared similar distribution of tet $(\mathrm{M})$ types, with Type 1 dominant, while $\mathrm{W} 2$ and $\mathrm{S} 1$ shared a similar pattern, with Type 5 dominant. The distribution patterns of tet(M) types in different samples suggested that some tet genes in the influent may originate from the OTC producing wastes, probably by gene transfer, while others occurred in the effluent and sludge under the selection pressure of high antibiotic concentrations. As for tet(C), Type 1 detected in all samples at high proportions was identical to the known sequences obtained from the NCBI GenBank, which were conservative based on homology analysis. New types of tet(C) (Types 2-4) only occurred at low frequencies in OTC-FR and OTC-ML, where the antibiotic selection pressure was extremely strong.

tet $(\mathrm{X})$ encodes an NADP-dependent monooxygenase that catalyzes the degradation of tetracyclines. ${ }^{51}$ tet $(\mathrm{X})$ was found at low levels in the influent, but showed a high abundance in the effluent and activated sludge of the APW treatment system (SI Table S6). The sequences of tet(X) in the APW treatment system were $100 \%$ identical to those found in the two reported host bacteria Bacteroides and Sphingobacterium. ${ }^{52,53}$ Although OTC is considered difficult to biodegrade, ${ }^{32,54}$ the high abundance of tet $(\mathrm{X})$ in the activated sludge suggests that tet $(\mathrm{X})$ may have been selected for some unknown function under the high residual OTC levels, which warrants further study.

This study revealed for the first time that the relative abundance of tet genes and mobile elements in treated effluent and sludge from the APW treatment system was higher than those in the OTC fermentation residues which have been listed as hazardous wastes $(P<0.01)$, and higher than STPs and the control systems $(P<0.01)$, making it essential to manage these routes in relation to ARGs. The dominance of the EFP genes tet $(\mathrm{A}), \operatorname{tet}(\mathrm{C})$, and $\operatorname{tet}(\mathrm{G})$ in the APW treatment system was related with the bacterial community compositions and the presence of intI1. Further studies are necessary to explore the 
proliferation pathways of ARGs under high antibiotic selection pressure in APW treatment systems.

\section{ASSOCIATED CONTENT}

\section{S Supporting Information}

Flowchart and sampling sites of the OTC production wastes (Figure S1.a) and the APW treatment system (Figure S1.b); Relative abundance of tet genes and intI1 (gene copies per 16S rRNA gene) in the influent (W1) and effluent (W2) (Figure S2); Correlation between the relative abundances of tet $(\mathrm{M})$ and Tn916/1545 (Figure S3); Neighbor-joining phylogenetic tree of representative tet $(\mathrm{C})$ gene sequences (Figure S4); Neighborjoining phylogenetic tree of representative tet $(\mathrm{M})$ gene sequences (Figure S5); Neighbor-joining phylogenetic tree of representative tet $(\mathrm{X})$ gene sequences (Figure S6); Correlations between the relative abundance of $\operatorname{tet}(\mathrm{A}), \operatorname{tet}(\mathrm{C}), \operatorname{tet}(\mathrm{G})$ and intI1 (gene copies per 16S rRNA gene) for samples from the APW treatment system (Figure S7); Chemical and biological characteristics of the wastewater (Table S1); Concentrations of OTC and its hydrolysates in wastewater (Table S2); Primers, PCR conditions used in this study (Table S3); The detection limit, standard curve, and amplification efficiency of Sybr-Green real-time PCR (Table S4); Copies of tet genes per sample volume (Table S5) and per 16S rRNA gene (Table S6); Distribution of phylogenetic groups among tet(C) clone libraries (Table S7); Distribution of phylogenetic groups among 16S rRNA clone libraries (Table S8); Comparison of the relative abundance of tet genes and mobile elements in the effluent and activated sludge from the APW treatment system and those from STPs and control systems (Table S9). This material is available free of charge via the Internet at http:// pubs.acs.org.

\section{AUTHOR INFORMATION}

\section{Corresponding Author}

*E-mail: yangmin@rcees.ac.cn.

\section{Notes}

The authors declare no competing financial interest.

\section{ACKNOWLEDGMENTS}

This study was supported by National Natural Scientific Foundation of China (NSFC 51178449, 50921064, 20877085). We greatly thank Mr. Huimin Wei, Mr. Ran Ding, Dr. Haifeng Zhang, and Dr. Kuixiao Li for their kind help in sampling and analysis, and we thank Dr. Jupei Shen, and Dr. Limei Zhang for their valuable suggestions on this work.

\section{REFERENCES}

(1) Levy, S; Marshall, B. Antibacterial resistance worldwide: Causes, challenges and responses. Nat. Med. 2004, 10, S122-129.

(2) Goossens, H.; Guillemot, D; Ferech, M; Schlemmer, B; Costers, M; van Breda, M; Baker, L. J.; Cars, O; Davey, P. G. National campaigns to improve antibiotic use. Eur. J. Clin. Pharmacol. 2006, 62 (5), 373-379.

(3) Alderman, D.; Hastings, T. Antibiotic use in aquaculture: development of antibiotic resistance potential for consumer health risks. Int. J. Food. Sci. Technol. 1998, 33 (2), 139-155.

(4) Ministry of Environmental protection, PRC, No. 2008-81 (Aug 1, 2008).

(5) European Environmental Commission, No. 2000-532-EEC (Jun 9, 2000).

(6) Ministry of Agricultural and Ministry of Health, PRC, No. 2002176 (Feb 9, 2002).
(7) Ma, W. L.; Qi, R.; Zhang, Y.; Wang, J.; Liang, C. Z.; Yang, M. Performance of a successive hydrolysis, denitrification and nitrification system for simultaneous removal of COD and nitrogen from terramycin production wastewater. Biochem. Eng. J. 2009, 45 (1), $30-34$.

(8) Martinez, J. L. Environmental pollution by antibiotics and by antibiotic resistance determinants. Environ. Pollut. 2009, 157 (11), 2893-2902.

(9) Summers, A. O. Generally overlooked fundamentals of bacterial genetics and ecology. Clin. Infect. Dis. 2002, 34, S85-92.

(10) Li, D.; Yu, T.; Zhang, Y.; Yang, M.; Li, Z.; et al. Antibiotic Resistance Characteristics of Environmental Bacteria from an Oxytetracycline Production Wastewater Treatment Plant and the Receiving River. Appl. Environ. Microbiol. 2010, 76 (11), 3444-3451.

(11) Zhang, X.; Zhang, T. Occurrence, Abundance, and Diversity of Tetracycline Resistance Genes in 15 Sewage Treatment Plants across China and Other Global Locations. Environ. Sci. Technol. 2011, 45, 2598-2604.

(12) Koike, S.; Krapac, I. G.; Oliver, H. D.; Yannarell, A. C.; CheeSanford, J. C.; Aminov, R. I.; Mackie, R. I. Monitoring and source tracking of tetracycline resistance genes in lagoons and groundwater adjacent to swine production facilities over a 3-year period. Appl. Environ. Microbiol. 2007, 73 (15), 4813-4823.

(13) Smith, M. S.; Yang, R. K.; Knapp, C. W.; Niu, Y.; Peak, N.; Hanfelt, M. M.; Galland, J. C.; Graham, D. W. Quantification of tetracycline resistance genes in feedlot lagoons by real-time PCR. Appl. Environ. Microbiol. 2004, 70 (12), 7372-7377.

(14) Szczepanowski, R.; Linke, B.; Krahn, I.; Gartemann, K.; Gutzkow, T.; Eichler, W.; Puhler, A.; Schluter, A. Detection of 140 clinically relevant antibiotic-resistance genes in the plasmid metagenome of wastewater treatment plant bacteria showing reduced susceptibility to selected antibiotics. Microbiology 2009, 155, 23062319.

(15) Kim, S.; Park, H.; Chandran, K. Propensity of activated sludge to amplify or attenuate tetracycline resistance genes and tetracycline resistant bacteria: A mathematical modeling approach. Chemosphere 2010, 78 (9), 1071-1077.

(16) Peak, N.; Knapp, C. W.; Yang, R. K.; Hanfelt, M. M.; Smith, M. S.; Aga, D. S.; Graham, D. W. Abundance of six tetracycline resistance genes in wastewater lagoons at cattle feedlots with different antibiotic use strategies. Environ. Microbiol. 2007, 9 (1), 143-151.

(17) Chopra, I.; Roberts, M. Tetracycline antibiotics: Mode of action, applications, molecular biology, and epidemiology of bacterial resistance. Microbiol. Mol. Biol. Rev. 2001, 65 (2), 232-260.

(18) Li, D.; Yang, M.; Hu, J.; Ren, L.; Zhang, Y.; Li, K. Determination and fate of oxytetracycline and related compounds in oxytetracycline production wastewater and the receiving river. Environ. Toxicol. Chem. 2008, 27 (1), 80-86.

(19) Wei, F. S. Monitoring and Analysis Methods of Water and Wastewater, 4th ed.; Chinese Environmental Sciences Publishment: China, 2002.

(20) Sei, K.; Asano, K; Mori, K; Ike, M; Kohno, T; Fujita, M. Development of simple methods of DNA extraction from environmental samples for monitoring microbial community based on PCR. J .Water Treat. Biol. (Japanese) 2000, 36 (4), 193-204.

(21) Ng, L. K.; Martin, I.; Alfa, M.; Mulvey, M. Multiplex PCR for the detection of tetracycline resistant genes. Mol. Cell. Probes 2001, 15 (4), 209-215.

(22) Aminov, R. I.; Chee-Sanford, J. C.; Garrigues, N.; Teferedegne, B.; Krapac, I. J.; White, B. A.; Mackie, R. I. Development, validation, and application of PCR primers for detection of tetracycline efflux genes of gram-negative bacteria. Appl. Environ. Microbiol. 2002, 68 (4), $1786-1793$

(23) Aminov, R. I.; Garrigues-Jeanjean, N.; Mackie, R. I. Molecular ecology of tetracycline resistance: Development and validation of primers for detection of tetracycline resistance genes encoding ribosomal protection proteins. Appl. Environ. Microbiol. 2001, 67 (1), $22-32$. 
(24) Goldstein, C.; Lee, M. D.; Sanchez, S.; Hudson, C.; Phillips, B.; Register, B.; Grady, M.; Liebert, C.; Summers, A. O.; White, D. G. Incidence of class 1 and 2 integrases in clinical and commensal bacteria from livestock, companion animals, and exotics. Antimicrob. Agents Chemother. 2001, 45 (3), 723-726.

(25) Roberts, A. P.; Cheah, G.; Ready, D.; Pratten, J.; Wilson, M.; Mullany, P. Transfer of Tn916-like elements in microcosm dental plaques. Antimicrob. Agents Chemother. 2001, 45 (10), 2943-2946.

(26) Yu, Z.; Michel, F. C., Jr.; Hansen, G.; Wittum, T; Morrison, M. Development and application of real-time PCR assays for quantification of genes encoding tetracycline resistance. Appl. Environ. Microbiol. 2005, 71 (11), 6926-6933.

(27) Pei, R.; Kim, S. C.; Carlson, K. H.; Pruden, A. Effect of river landscape on the sediment concentrations of antibiotics and corresponding antibiotic resistance genes (ARG). Water Res. 2006, 40 (12), 2427-2435.

(28) Knapp, C. W.; Engemann, C. A.; Hanson, M. L.; Keen, P. L.; Hall, K. J.; Graham, D. W. Indirect evidence of transposon-mediated selection of antibiotic resistance genes in aquatic systems at low-level oxytetracycline exposures. Environ. Sci. Technol. 2008, 42 (14), 53485353.

(29) DeLong, E. F. Archaea in coastal marine environments. Proc. Natl. Acad. Sci. 1992, 89 (12), 5685-5689.

(30) Schloss, P. D.; Handelsman, J. Introducing DOTUR, a computer program for defining operational taxonomic units and estimating species richness. Appl. Environ. Microbiol. 2005, 71 (3), $1501-1506$

(31) Dairi, T.; Aisaka, K.; Katsumata, R.; Hasegawa, M. A self-defense gene homologous to tetracycline effluxing gene essential for antibiotic production in Streptomyces aureofaciens. Biosci. Biotechnol. Biochem. 1995, 59 (10), 1835-1841.

(32) Wu, N.; Qiao, M; Zhang, B; Cheng, W. D.; Zhu, Y. G. Abundance and Diversity of Tetracycline Resistance Genes in Soils Adjacent to Representative Swine Feedlots in China. Environ. Sci. Technol. 2009, 44, 6933-6939.

(33) Kim, S.; Eichhorn, P.; Jensen, J. N.; Weber, A. S.; Aga, D. S. Removal of antibiotics in wastewater: Effect of hydraulic and solid retention times on the fate of tetracycline in the activated sludge process. Environ. Sci. Technol. 2005, 39 (15), 5816-5823.

(34) Batt, A. L.; Kim, S.; Aga, D. S. Comparison of the occurrence of antibiotics in four full-scale wastewater treatment plants with varying designs and operations. Chemosphere 2007, 68 (3), 428-435.

(35) Pena, A.; Paulo, M.; Silva, L. J. G.; Seifrtová, M.; Lino, C. M.; Solich, P. Tetracycline antibiotics in hospital and municipal wastewaters: A pilot study in Portugal. Anal. Bioanal. Chem. 2010, 396 (8), 2929-2936.

(36) Mackie, R. I.; Koike, S.; Krapac, I.; Chee-Sanford, J.; Maxwell, S.; Aminov, R. I. Tetracycline residues and tetracycline resistance genes in groundwater impacted by swine production facilities. Animal Biotechnol. 2006, 17 (2), 157-176.

(37) Tylova, T.; Olsovska, J.; Novak, P.; Flieger, M. High-throughput analysis of tetracycline antibiotics and their epimers in liquid hog manure using Ultra Performance Liquid Chromatography with UV detection. Chemosphere 2010, 78 (4), 353-359.

(38) Ghosh, S.; Ramsden, S. J.; LaPara, T. M. The role of anaerobic digestion in controlling the release of tetracycline resistance genes and class 1 integrons from municipal wastewater treatment plants. Appl. Microbiol. Biotechnol. 2009, 84 (4), 791-796.

(39) Munir, M.; Wong, K.; Xagoraraki, I. Release of Antibiotic Resistant Bacteria and Genes in the Effluent and Biosolids of Five Wastewater Utilities in Michigan. Water Res. 2010, 45, 681-693.

(40) David, L. D.; Lapara, T. M. Effect of temperature on the fate of genes encoding tetracycline resistance and the integrase of Class 1 integrons within anaerobic and aerobic digesters treating municipal wastewater solids. Environ. Sci. Technol. 2010, 44, 9128-9133.

(41) $\mathrm{Hu}, \mathrm{J}$; Shi, J; Chang, H; Li, D; Yang, M; Kamagata, Y. Phenotyping and genotyping of antibiotic-resistant Escherichia coli isolated from a natural river basin. Environ. Sci. Technol. 2008, 42 (9), $3415-3420$.
(42) Hopwood, D. A. How do antibiotic producing bacteria ensure their self resistance before antibiotic biosynthesis incapacitates them? Mol. Microbiol. 2007, 63 (4), 937-940.

(43) Cundliffe, E. How antibiotic-producing organisms avoid suicide. Annu. Rev. Microbiol. 1989, 43 (1), 207-233.

(44) Hall, R. M.; Collis, C. M. Mobile gene cassettes and integrons: Capture and spread of genes by site-specific recombination. Mol. Microbiol. 1995, 15 (4), 593-600.

(45) Ochman, H.; Lawrence, J. G.; Groisman, E. A. Lateral gene transfer and the nature of bacterial innovation. Nature 2000, 405 (6784), 299-304.

(46) Gillings, M.; Boucher, Y.; Labbate, M.; Holmes, A.; Krishnan, S.; Holley, M.; Stokes, H. W. The evolution of class 1 integrons and the rise of antibiotic resistance. J. Bacteriol. 2008, 190 (14), 5095-5100.

(47) Toleman, M. A.; Bennett, P. M.; Walsh, T. R. ISCR elements: Novel gene-capturing systems of the 21st century? Microbiol. Mol. Biol. Rev. 2006, 70 (2), 296-316.

(48) Schnabel, E. L.; Jones, A. L. Distribution of tetracycline resistance genes and transposons among phylloplane bacteria in Michigan apple orchards. Appl. Environ. Microbiol. 1999, 65 (11), 4898-4907.

(49) Agersø, Y.; Sandvang, D. Class 1 integrons and tetracycline resistance genes in Alcaligenes, Arthrobacter, and Pseudomonas spp. isolated from pigsties and manured soil. Appl. Environ. Microbiol. 2005, 71 (12), 7941-7947.

(50) Rizzotti, L.; La Gioia, F.; Dellaglio, F.; Torriani, S. Molecular diversity and transferability of the tetracycline resistance gene tet $(\mathrm{M})$, carried on Tn916-1545 family transposons, in enterococci from a total food chain. Antonie Van Leeuwenhoek. 2009, 96 (1), 43-52.

(51) Yang, W.; Moore, I. F.; Koteva, K. P.; Bareich, D. C.; Hughes, D. W.; Wright, G. D. TetX is a flavin-dependent monooxygenase conferring resistance to tetracycline antibiotics. J. Biol. Chem. 2004, 279 (50), 52346-52352.

(52) Ghosh, S.; Sadowsky, M. J.; Roberts, M. C.; Gralnick, J. A.; LaPara, T. M. Sphingobacterium sp. strain PM2-P1-29 harbours a functional tet $(\mathrm{X})$ gene encoding for the degradation of tetracycline. $J$. Appl. Microbiol. 2009, 106 (4), 1336-1342.

(53) Whittle, G.; Shoemaker, N.; Salyers, A. The role of Bacteroides conjugative transposons in the dissemination of antibiotic resistance genes. Cell. Mol. Life Sci. 2002, 59 (12), 2044-2054.

(54) Li, B.; Zhang, T. Biodegradation and Adsorption of Antibiotics in the Activated Sludge Process. Environ. Sci. Technol. 2010, 44 (9), $3468-3473$. 